\title{
Pengaruh Employee Engagement dan Kepemimpinan terhadap Kinerja Pegawai pada Dinas Pariwisata, Budaya, Pemuda dan Olah Raga Kabupaten Serdang Bedagai
}

\author{
${ }^{1)}$ Anggia Sari Lubis, ${ }^{2}$ Sari Wulandari \\ 1) Fakultas Ekonomi, Universitas Muslim Nusantara Al Washliyah \\ email: anggiasarilubis@gmail.com \\ 2) Fakultas Ekonomi, Universitas Muslim Nusantara Al Washliyah \\ e-mail: wulanda21.wd@gmail.com
}

\begin{abstract}
Abstrak
Tujuan dari penelitian ini adalah untuk mengetahui dan menganalisis apakah employee engagement dan kepemimpinan berpengaruh secara simultan dan parsial terhadap kinerja pegawai pada dinas pemuda olahraga, kebudayaan, pariwisata Kabupaten Serdang Bedagai.Hasil penelitian yang telah memenuhi uji validitas, uji reliabilitas dan uji asumsi klasik diolah sehingga menghasilkan persamaan regresi sebagai berikut, $\boldsymbol{Y}=\mathbf{0 , 0 3 0} X \mathbf{1}+\mathbf{0 . 2 4 6} \mathbf{X} \mathbf{2}+\boldsymbol{e}$. Hasil model regresi linier berganda mendapatkan bahwa kedua variabel yaitu employee engagement dan kepemimpinan memiliki pengaruh positif terhadap kinerja pegawai Dinas Pariwisata Budaya Pemuda dan Olahraga. Nilai koefisien determinasi $\left(R^{2}\right)$ yang diperoleh sebesar 0,631. Hal ini berarti 63,1\% kinerja pegawai dapat dijelaskan oleh variabel employee engagement dan kepemimpinan. Berdasarkan hasil uji secara parsial (Uji t) diperoleh bahwa variabel yang paling dominan dalam mempengaruhi kinerja karyawan adalah variabel kepemimpinan.
\end{abstract}

Kata kunci: Employee Engagement, Kepemimpinan, Kinerja Pegawai

\section{PENDAHULUAN}

Dinas Pemuda Olahraga, Kebudayaan, Pariwisata dan merupakan instansi pemerintah daerah yang berada di Provinsi maupun di Kabupaten/Kota, yang memiliki tugas dan fungsi untuk membina serta mengembangkan bidang kepemudaan, keolahragaan, kebudayaan dan pariwisata di Provinsi maupun di Kabupaten/Kota sesuai dengan kebijakan yang ditetapkan oleh pemerintah daerah dan sesuai dengan undangundang yang berlaku. Memiliki banyak bidang dan seksi yang tugas utamanya antara lain melakukan kegiatan-kegiatan seperti kegiatan pelatihan kepemimpinan dan kewirausahaan yang bertujuan untuk memberdayakan pemuda. Selain itu tugas utama berikutnya adalah melakukan kegiatan yang bertujuan untuk meningkatkan prestasi dibidang olahraga, melestarikan kebudayaan, serta melakukan kegiatan promosi pariwisata untuk memperkenalkan budaya dan objek wisata yang ada di Kabupaten Serdang Bedagai.

Untuk mencapai keberhasilan dalam pelaksanaan tugas-tugas dan fungsi di setiap bidang dan seksi, diperlukan pencapaian kinerja yang tinggi dari para pegawai. Pegawai yang professional dengan kinerja tinggi dapat diperoleh melalui pemberdayaan konsep employee engagement. Employee Engagement merupakan konsep dan cara kerja yang dirancang untuk memastikan bahwa para pegawai berkomitmen untuk tujuan dan nilai-nilai perusahaan tempat karyawan bekerja, 
termotivasi untuk memberikan kontribusi bagi keberhasilan perusahaan atau dalam hal ini adalah Dinas, dan pada saat yang sama agar mampu meningkatkan rasa kesejahteraan diri. Masih banyak perusahaan yang belum menerapkan konsep employee engagement ini.

Padahal organisasi yang menerapkan sistem kerja ataupun konsep employee engagement ini akan memiliki kekuatan dan nilai otentik, dengan bukti yang jelas dari kepercayaan dan keadilan yang didasarkan pada saling menghormati, di mana keduanya memiliki janji dan komitmen antara employer dan employee yang dipahami dan terpenuhi (McLeod, 2009). Berdasarkan studi dinyatakan bahwa keterikatan individu pegawai dengan organisasi dibentuk oleh keterikatan emosional dan faktor rasional yang berhubungan dengan pengalaman kerja dan lingkungan kerja. Keterikatan individu pegawai adalah suatu hasrat, niat dan komitmen untuk menginvestasikan waktu, kemampuan disertai dengan kesediaan untuk mengorbankan sebagian kepentingan pribadi individu pada pencapaian sasaran dan tujuan organisasi di masa yang akan datang melebihi upaya untuk mewujudkan kepuasan individu dan menunjukkan loyalitas pada organisasi. Jika karyawan sudah memiliki sistem kerja seperti ini, otomatis pencapaian kinerja karyawan yang tinggi akan mudah diperoleh.

Corporate Leadership Council (2004) dalam Annisa (2013), menyatakan bahwa dengan meningkatkan keterikatan pegawai, organisasi dapat mengalami peningkatan sebanyak 20 poin persentil dalam kinerja pegawai. Penelitian ini juga mengungkapkan bahwa pegawai yang memiliki keterikatan menunjukkan pengurangan $87 \%$ dalam probabilitas meninggalkan organisasi. Selain konsep employee engagement, faktor lain yang memberikan kontribusi untuk peningkatan kinerja pegawai adalah konsep kepemimpinan.Kepemimpinan (leadership) merupakan cara dari seorang pemimpin (leader) dalam mengarahkan, mendorong dan mengatur seluruh unsurunsur di dalam kelompok atau organisasinya untuk mencapai suatu tujuan organisasi yang diinginkan sehingga menghasilkan kinerja pegawai yang maksimal.

Persoalan yang terjadi adalah sumber daya manusia yang ada di dalam organisasi sering mengalami konflik baik antara sesama pegawai maupun antara pegawai dengan pemimpin. Untuk menghindari konflik tersebut, maka para pegawai dalam melaksanakan pekerjaannya, perlu diarahkan untuk saling bekerja sama di dalam suatu kesatuan utuh dan, tidak secara terpisah. Maju mundurnya suatu perusahaan akan bergantung pada seorang pemimpin dengan kepemimpinan yang dijalankan dalam mengelola organisasi. Selain itu, pemimpin sebagai orang yang memiliki kemampuan, kompetensi, distribusi kekuasaan, serta melibatkan pihak lain, akan memberikan peranan besar bagi kelangsungan hidup organisasi. Berdasarkan uraian latar belakang dan perumusan masalah, maka tujuan penelitian ini adalah untuk mengetahui dan menganalisis employee engagement dan kepemimpinan berpengaruh secara simultan dan parsial terhadap kinerja pegawai Dinas Pariwisata, Budaya,Pemuda dan Olah Raga Kabupaten Serdang Bedagai. 


\section{TINJAUAN PUSTAKA}

\section{Employee Engagement}

Employee engagement merupakan rasa keterikatan secara emosional dengan pekerjaan dan organisasi, termotivasi dan mampu memberikan kemampuan terbaik mereka untuk membantu sukses dari serangkaian manfaat nyata bagi organisasi dan individu, (MacLeod, 2009). Organisasi yang engaged memiliki kekuatan dan nilai otentik, dengan bukti yang jelas dari kepercayaan dan keadilan yang didasarkan pada saling menghormati, di mana keduanya memiliki janji dan komitmen antara employer dan employee yang dipahami dan terpenuhi, (MacLeod, 2009).

Engagement didefinisikan sebagai sikap yang positif, penuh makna, dan motivasi, yang dikarakteristikkan dengan vigor, dedication, dan absorption (Schaufeli, 2002 dalam Breso, Schaufeli, \& Salanova, 2010). Vigor dikarakteristikkan dengan tingkat energi yang tinggi, resiliensi, keinginan untuk berusaha, dan tidak menyerah dalam menghadapi tantangan. Dedication ditandai dengan merasa bernilai, antusias, inspirasi, berharga dan menantang. Absorption ditandai dengan konsentrasi penuh terhadap suatu tugas, (Schaufeli \& Bakker, 2003). Dari berbagai definisi yang dikemukakan oleh beberapa tokoh di atas, dapat ditarik kesimpulan bahwa employee engagement adalah sebagai sikap yang positif yang dimiliki karyawan dengan penuh makna, dan energi motivasi yang tinggi, resiliensi dan keinginan untuk berusaha, dan tidak menyerah dalam menghadapi tantangan dengan konsentrasi penuh terhadap suatu tugas yang disesuaikan dengan nilai dan tujuan organisasi.

\section{Kepemimpinan}

Kepemimpinan adalah kemampuan untuk menpengaruhi dan menggerakan orang lain untuk mencapai tujuan. Kepemimpinan dalam organisasi diarahkan untuk mempengaruhi orang - orang yang dipimpinnya, agar mau berbuat seperti yang diharapkan ataupun diarahkan oleh orang yang memimpinnya. Menurut Hoyt dalam Kartono (2003) menyatakan kepemimpinan adalah seni untuk mempengaruhi tingkah laku manusia, kemampuan untuk membimbing orang. Kepemimpinan menurut Young dalam Kartono (2003) lebih terarah dan terperinci dari definisi sebelumnya. Seorang pemimpin yang baik haruslah mampu mempergunakan wewenang dan kepemimpinannya untuk dapat mencapai suatu tujuan organisasi. Dasar kepemimpinan merupakan gaya seorang pemimpin untuk mempengaruhi bawahannya agar mau bekerja sama dan bekerja secara efektif sesuai dengan perintahnya. Menurut Yukl (2005) selain karekteristik seorang pemimpin yang baik harus memiliki pengaruh dan peranan penting dalam melakukan hal berikut ini:

1. Memotivasi anggota untuk dapat mencapai tujuan

2. Rasa saling percaya dan bekerjasama antar angota

3. Pembelajaran dan pembagian pengetahuan baru antar anggota

4. Organisasi aktivitas kerja

5. Pencapaian tujuan dan strategi yang dicapai

6. Pengembangan kepercayaan dan keterampilan antar anggota 
Indikator Kepemimpinan menurut Chapman dalam Gitosudarmo dan Sudita (1997) yaitu cara berkomunikasi, pemberian motivasi, kemampuan memimpin, pengambilan keputusan dan kekuasaan yang positif.

\section{Kinerja Pegawai}

Pengertian kinerja atau performance merupakan gambaran mengenai tingkat pencapaian pelaksanaan suatu program kegiatan atau kebijakan dalam mewujudkan sasaran, tujuan, visi, dan misi organisasi yang dituangkan melalui perencanaan strategis suatu organisasi (Moeheriono, 2009). Kinerja dapat diketahui dan diukur jika individu atau sekelompok karyawan telah mempunyai kriteria atau standar keberhasilan tolok ukur yang telah ditetapkan oleh organisasi. Menurut Gomes (1995) dalam Mangkunegara (2009) menyatakan kinerja karyawan sebagai ungkapan seperti output, efisiensi serta efektivitas yang sering dihubungkan dengan produktivitas. Selanjutnya Mangkunegara (2009) menyatakan bahwa kinerja karyawan adalah hasil kerja secara kualitas dan kuantitas yang dicapai oleh seseorang karyawan dalam melaksanakan tugasnya sesuai dengan tanggung jawab yang diberikan kepada karyawan tersebut. Kinerja individual merupakan hubungan dari ketiga factor antara lain kemampuan (ability), usaha (effort), dan dukungan (support).

Kinerja individual ditingkatkan sampai tingkat di mana ketiga komponen tersebut ada di dalam diri karyawan. Akan tetapi, kinerja berkurang apabila salah satu faktor ini dikurang atau tidak ada (Mathis dan Jackson, 2006). Sedangkan Robbins (2003) dalam Moeheriono (2009) menyatakan bahwa kinerja merupakan fungsi interaksi antara kemampuan (ability), motivasi (motivation), dan kesempatan (opportunity). Artinya bahwa kinerja merupakan fungsi dari kemampuan, motivasi, dan kesempatan.

\section{Hipotesis}

Hipotesis yang akan diuji dalam penelitian ini adalah:

1. Employee engagement dan kepemimpinan secara parsial berpengaruh signifikan terhadap kinerja pegawai pada dinas pemuda olahraga, kebudayaan, pariwisata Kabupaten Serdang Bedagai

2. Employee engagement dan kepemimpinan secara simultan berpengaruh signifikan terhadap kinerja pegawai pada dinas pemuda olahraga, kebudayaan, pariwisata Kabupaten Serdang Bedagai

\section{METODE PENELITIAN}

\section{Populasi Dan Sampel}

Populasi adalah keseluruhan subjek penelitian (Lubis, 2012). Populasi yang digunakan dalam penelitian ini adalah seluruh pegawai Dinas Pariwisata, Budaya,Pemuda dan Olah Raga Kabupaten Serdang Bedagai".Sampel adalah sebagian atau wakil populasi yang diteliti (Lubis, 2012). Metode pengambilan sampel yang digunakan adalah metode survey, dimana seluruh populasi dijadikan sampel dalam penelitian ini. Sehingga seluruh pegawai Dinas Pariwisata, Budaya,Pemuda dan Olah Raga Kabupaten Serdang Bedagai yang berjumlah 70 orang merupakan responden dalam penelitian ini. 


\section{Metode Pengumpulan Data}

Metode pengumpulan data yang digunakan dalam penelitian ini adalah:

1. Wawancara (interview), yang dilakukan kepada Kepala Dinas, Kepala Bidang dan Kepala Seksi pada Dinas Pariwisata, Budaya,Pemuda dan Olah Raga Kabupaten Serdang Bedagai atau pihakpihak lain yang ditunjuk oleh organisasi untuk memberikan informasi dan keterangan yang dibutuhkan dalam penelitian ini.

2. Daftar pertanyaan (questionairre), yang diberikan kepada pegawai Dinas Pariwisata, Budaya,Pemuda dan Olah Raga Kabupaten Serdang Bedagai yang menjadi responden dalam penelitian ini.

3. Studi dokumentasi, dilakukan dengan mengumpulkan dan mempelajari dokumen-dokumen yang diperoleh dari Dinas Pariwisata, Budaya,Pemuda dan Olah Raga Kabupaten Serdang Bedagai yang berupa sejarah singkat berdirinya organisasi, struktur organisasi, jumlah pegawai, serta detail dan jenis pengembangan sumber daya manusia.

\section{HASIL DAN PEMBAHASAN}

\section{Analisis Regresi Linier Berganda}

Berdasarkan dari hasil analisis dengan program SPSS maka diperoleh hasil regresi antara employee engagement dan kepemimpinan terhadap kinerja pegawai adalah sebagai berikut:

\section{Tabel 1. Hasil Analisis Statistik}

\begin{tabular}{lccc}
\hline \multicolumn{1}{c}{ Variabel } & $\mathrm{B}$ & $\mathrm{t}$ & Sig. t \\
\hline Konstanta & 23,770 & 5,387 &, 000 \\
employee engagement & 0,030 & 0,236 &, 814 \\
kepemimpinan & 0,246 & 2,979 &, 004 \\
\hline Adjusted R. Square & $=0,605$ & & \\
F & $=35,029$ & & \\
Sig. F & $=, 013$ & & \\
\hline
\end{tabular}

Sumber: Data Primer diolah, 2017

Dari hasil regresi maka dapat dibuat persamaan regresi berganda sebagai berikut:

$$
\mathrm{Y}=\mathbf{2 3 . 7 7 0}+\mathbf{- 0 . 0 3 0} \mathrm{X} 1+0.246 \mathrm{X} 2+\mathrm{e}
$$

Persamaan regresi tersebut mempunyai arti sebagai berikut:

1. Nilai konstanta sebesar 1,782 merupakan nilai kinerja pegawai sebelum dipengaruhi oleh employee engagement dan kepemimpinan.

2. Koefisien regresi employee engagement (b1) bernilai positif sebesar 0,030, hal ini menunjukkan employee engagement berpengaruh positif terhadap kinerja pegawai. Peningkatan employee engagement dalam satu satuan unit, akan diikuti dengan peningkatan kinerja pegawai sebesar $3.0 \%$. 
3. Koefisien regresi kepemimpinan (b2) bernilai positif sebesar 0,246, hal ini menunjukkan kepemimpina berpengaruh positif terhadap kinerja pegawai. Peningkatan kepemimpinan dalam satu satuan unit, akan diikuti dengan peningkatan kinerja pegawai sebesar 24,6\%.

\section{Uji Secara Parsial (Uji t)}

Hasil pengujian hipotesis secara parsial dapat dilihat pada tabel 1, dimana diperoleh hasil sebagai berikut:

1. Nilai $t_{\text {hitung }}$ untuk variabel employee engagement 0.236 lebih kecil dibandingkan nilai $t_{\text {tabel }}(2.000)$, atau nilai sig t untuk variable employee engagement $(0,814)$ lebih besar dari alpha $(0,025)$. Ini berarti employee engagement berpengaruh positif tetapi tidak signifikan terhadap kinerja pegawai Dinas pariwisata,budaya pemuda dan olahraga Kabupaten Serdang Bedagai. Employee engagement hanya memiliki pengaruh yang kecil dan tidak signifikan terhadap kinerja pegawai, karena rendahnya hubungan emosional dan intelektual yang dimiliki oleh pegawai terhadap pekerjaannya. Pada dasarnya terjalinnya hubungan yang baik dengan pekerjaan yang menjadi tanggung jawab pegawai, harus didukug oleh pemimpin sebuah organisasi dengan memberikan dukungan dan nasehat, serta dukungan dari atau rekan kerja yang saling mendukung, sehingga membuat pegawai dapat memberikan upaya terbaik dalam mencapai kualitas pekerjaan yang baik.

2. Nilai $t_{\text {hitung }}$ untuk variabel kepemimpinan yaitu $(2,979)$ lebih besar dibandingkan dengan nilai $t_{\text {tabel }}$ (2.000), atau nilai sig t untuk variable kompetensi sumber daya manusia (0.004) lebih kecil dari alpha (0,025). Ini berarti kepemimpinan berpengaruh terhadap kinerja pegawai Dinas pariwisata, budaya, pemuda dan olahraga Kabupaten Serdang Bedagai. Ini berarti praktek yang dijalankan pemimpin berpengaruh terhadap kinerja pegawai. Berkaitan dengan peningkatan kinerja pegawai, peranan kepemimpinan merupakan hal yang tidak dapat dipisahkan. Pemimpin yang efektif adalah, seorang pemimpin yang mampu mempengaruhi orang lain dengan berbagai tipe kombinasi kekuasaan agar dapat mencapai tujuan organisasi.

\section{Uji Secara Serempak (Uji F)}

Hasil pengujian hipotesis secara serempak dapat dilihat pada tabel 1 , dimana nilai $F_{\text {hitung }}$ (35.029) lebih besar dibandingkan dengan nilai $\mathrm{F}_{\text {tabel }}(3.15)$ dan sig.F $\left(.000^{\mathrm{a}}\right)$ lebih kecil dari alpha $5 \%$ $(0,05)$. Hal ini mengindikasikan bahwa hasil penelitian menolak H0 dan menerima Ha. Dengan demikian secara serempak employee engagement dan kepemimpinan berpengaruh signifikan terhadap kinerja pegawai. Ini memberi arti bahwa employee engagement dan kepemimpinan menentukan dalam meningkatkan kinerja pegawai.

\section{Uji Koefisien Determinasi}

Berdasarkan tabel 1, diperoleh nilai Adjusted R Square sebesar 0,605 dan mendekati angka 1, dengan demikian employee engagement dan kepemimpinan mampu menjelaskan hampir semua variasi dari variable kinerja pegawai, sehingga model regresi yang digunakan fit atau baik. Berdasarkan nilai 
$\mathrm{R}$ Square dapat diartikan pula employee engagement dan kepemimpinan mampu mempengaruhi kinerja karyawan yaitu sebesar $63,1 \%$.

\section{KESIMPULAN DAN SARAN}

\section{Kesimpulan}

Dari hasil analisis data dan pembahasan yang telah dilakukan dalam penelitian ini serta sesuai dengan tujuan penelitian, maka dapat disimpulkan sebagai berikut:

1. Hasil dari uji regresi menunjukkan bahwa kedua variabel independen, yaitu employee engagement dan kepemimpinan memiliki nilai positif. Artinya, semakin baik yang ada di dalam diri para pegawai, semakin baik praktek kepemimpinan yang dilakukan di dalam organisasi maka kinerja pegawai Dinas pariwisata budaya pemuda dan olah raga Kabupaten Serdang Bedagai akan semakin tinggi.

2. Variabel kepemimpinan berpengaruh paling besar, yaitu sebesar 2,979 terhadap kinerja pegawai Dinas pariwisata budaya pemuda dan olah raga Kabupaten Serdang Bedagai. Variabel employee engagement memiliki pengaruh yang cukup kecil yaitu sebesar 0,236.

3. Hasil uji F, secara simultan kedua variabel independen yaitu employee engagement dan kepemimpinan berpengaruh signifikan terhadap variabel kinerja pegawai dengan nilai signifikansi sebesar 0,013 .

4. Uji koefisien determinasi sebesar 0,631 menunjukkan bahwa variabel kinerja pegawai dapat dijelaskan $63,1 \%$ oleh variabel employee engagement dan kepemimpinan. Sedangkan sisanya $36,9 \%$ dipengaruhi variabel lain di luar penelitian ini.

\section{Saran}

Adapun saran yang diberikan dalam penelitian ini adalah:

1. Untuk meningkatkan kinerja pegawai pada Dinas pariwisata budaya pemuda dan olah raga Kabupaten Serdang Bedagai, maka sebagai pemimpin dalam organisasi harus mampu menegakkan ketegasan untuk mencapai visi dan misi organisasi, memberikan pengarahan dan instruksi terhadap pegawai, serta menjadi contoh dan teladan kepada bawahan (pegawai) dalam hal kedisiplinan dan kinerja.

2. Untuk penelitian yang akan dilakukan di masa yang akan datang, maka diharapkan dapat menambah variabel independen lainnya selain employee engagement dan kepemimpinanyang tentunya dapat mempengaruhi variabel dependen kinerja pegawai.

\section{REFERENSI}

Bacal, Robert. 2001. Performance Management. Jakarta: Gramedia Pustaka Utama.

Becker, Brian E, Mark A Huselid, Dave Ulrich .2009. The HR Score Card. Jakarta: Penerbit Erlangga

Cooper, Donald R, Pamela Schlinder. 2006. Metode Riset Bisnis . Jakarta: Media Global Edukasi

Dessler, Gary, Agus Dharma. 2005. Manajemen Personalia. Jakarta : Penerbit Erlangga 
Erlina . 2008. Metodologi Penelitian Bisnis Untuk Akuntansi dan Manajemen. Medan: USU Press Ghozali, Imam . 2009. Aplikasi Analisis Multivariate Dengan Program SPSS. Semarang: Badan Penerbit Universitas Diponegoro

Gomes, Faustino Cardoso. 2003. Manajemen Sumber Daya Manusia. Yogyakarta: Andi Offset. Grensing-Pophal, Lin. 2008. Human Resource Book. Jakarta: Prenada.

Hariandja, Marihot Tua Effendi. 2002. Manajemen Sumber Daya Manusia. Cetakan pertama. Jakarta: Gramedia Widia Sarana.

Hasibuan, Malayu SP . 2007. Manajemen Sumber Daya Manusia. Jakarta: Bumi Aksara.

Ivancevich, John, Robert Konopaske, Michael T Matteson. 2006. Perilaku Organisasi. Jakarta: Penerbit Erlangga

Kartono, Kartini. 2003. Pemimpin Dan Kepemimpinan. Jakarta: PT. Raja Grafindo Persada MacLeod, D. and Clarke, N. 2009. Engaging For Success: Enhancing Performance Through Employee Engagement. a Report To Government. London: Department for Business, Innovation and Skills.

Mangkunegara. 2000. Sumber Daya Manusia Perusahaan. Bandung: Penerbit Rosdakarya. Martoyo, Susilo. 2007. Manajemen Sumber Daya Manusia. Jakarta: BPFE

Mathis, Robert, John H Jackson. 2006. Manajemen Sumber Daya Manusia. Jakarta: Salemba 